mosis, a temporary paralysis in the lower limbs-a so-called reflex paraplegia. In the Planaria the primordial liver consists of nothing more than a few cells scattered along a tract of the intestinal surface, which secrete efficiently for the requirements of the organism. As we ascend the scale of animal life, however, we find these cells by agglomeration and multiplication forming a distinctly projecting nodule from the perivisceral wall of the bowel into the perivisceral cavity, and eventually culminating in the production of that large and apparently independant organ-the liver. It is therefore a gland which, secreting into the intestinal canal, is developed from the coats of the gut. The existence here of a free nerve inter-communication is evidenced by the fact that the passage of a slightly acid fluid into the duodenum determines forthwith a copious secretion of bile, whilst that of an alkaline fluid produces little or no effect. Menorrhagia is a symptom frequently associated with pyonephrosis in the early days, and more especially when this disease appears on the left side of the body. It is the manifestation of a mere augmented and prolonged functional activity of the uterus and Fallopian tube, determined in some occult manner by the condition of the renal organ, whilst the periodicity of the flow itself is undisturbed. In such cases I have failed during life to detect any evidence of disease in the generative tract, and have twice verified this fact by a careful examination of the body after death, the uterus, Fallopian tubes, and ovaries being perfectly healthy.

Montague-street, Russell-square, W.C.

\section{PREGNANCY COMPLICATED WITH OVARIAN TUMOURS TAPPING, DELIVERY, AND SUBSEQUENT REMOVAL OF CYSTS.}

By H. F. BAILIY, M.R.C.S., L.S.A.

ON June 5th last I was called to a lady, aged twenty-nine, whom I was to attend in her first confinement. This was about a fortnight before term. I found the abdomen excessively large, and both legs œdematous, blue, and mottled. Palpation revealed fluctuation with distinct thrill, and percussion resonant flanks, with dulness over the rest of the abdomen.

The diagnosis was left ovarian cyst, and, as the tumour was very tense and the patient evidently in imminent danger from rupture of cyst, I tapped about two inches above the umbilicus and removed two gallons of ovarian fluid. Five days later labour came on, and with forceps a healthy female child was born. Lactation was permitted for three months, but the tumour again filling rapidly, the child was weaned.

On Sept. 14th I operated, aided by my partner, Dr. J. N. Miller, Mr. Cooper giving methylene. On opening the abdomen by a four-inch incision, not only was there the left cyst as diagnosed, but the right ovary was the seat of a second tumour, a very dense-walled dermoid cyst weighing $2 \mathrm{lb}$. I removed the left cyst in the usual way, tying the pedicle by transfixion with Chinese twist and returning it. The tumour of the right ovary was next removed in like manner, and its pedicle also returned. Only one adhesion of omentum required ligature and division. After thorough sponging of the cavity, the incision was closed with silk sutures passing through the whole thickness of the abdominal wall, a Keith's tube inserted, and the wound dusted with iodoform and dressed with Gamgee pads and strapping. The tube was emptied of coloured serum every six or eight hours for a couple of days, and then removed. The dermoid cyst contained epithelial matter and much hair, the whole mass having the appearance and consistence of mortar; the cysts and contents weighed over $26 \mathrm{lb}$. Recovery was uninterrupted; the evening temperature on the day of operation was $100^{\circ}$; pulse 88 . The next day the pulse and temperature were normal, and remained so.

Dr. Fenwick begs for information as to the relation of pulmonary phthisis to ovarian disease. In this case careful inquiry failed to elicit any family history of phthisis, but the patient's parents were first cousins. I suppose the right cyst had remained nearly stationary in size for years, nd that gestation determined the rapid growth of the left. Blackheath.

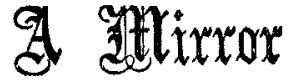

\section{HOSPITAL PRACTICE, BRITISH AND FOREIGN.}

Nulla autem est alia pro certo noscendi via, nisi quamplurimas et morborum et dissectionum historias, tum aliorum tum proprias collectas habere, et inter se comparare.-MorgagNI De Šed. et Caus. Morb., lib. iv. Proœmium.

\section{ST. GEORGE'S HOSPITAL.}

COMPOUND DEPRESSED FRACTURE OF THE VAULT OF THE SEULL; PARALYSIS OF THE RIGHT ARM; TREPHINING ; RECOVERY.

(Under the care of Mr. Pick.)

THE following belongs to the class of head injuries about which the rule as to operating is simple. The exact locality of the cerebral hemisphere on which there was pressure was doubtful, owing to the large area of bone depressed; but the centre of this area was easily ascertained by reference to Reid's base line. For the notes we are indebted to Mr. Bull, surgical registrar.

G. W-, aged sixteen, a milk-carrier, while delivering milk at some area steps was struck on the head by a falling ladder. $\mathrm{He}$ was picked up insensible. On admission (April 7th, 1886) he was unconscious, and bleeding from the nose and mouth. There was a semicircular scalp wound about two inches long over the left parietal bone, and at the bottom of this there was a ridge of bone and a depression about a quarter of an inch in depth. The extent of this depression could not be ascertained, as it passed beyond the full length of the scalp wound. There was slight twitching of the right arm. He vomited some blood, and became conscious four hours after admission. Next day he was restless and irritable. He answered questions, but was drowsy at times. There was slight paresis of the right arm, but no marked paralysis. He was able to move his legs, and had entire control over his sphincters. The bleeding from the nose and mouth had ceased. The wound was dressed and was looking quiet. Next day, forty-eight hours after the accident, the lad was more diowsy, and unless roused he lay quietly on his back. There was marked paralysis of the arm, and the grasp of the hand was very feeble.

After consultation, Mr. Pick (ether having been administered) made an incision across the wound, and reflected the soft tissues. A piece of bone measuring about $3 \mathrm{in}$. by 2 in. was depressed and wedged below the non-depressed part. The centre of this area was $2 \frac{1}{2}$ in. behind the left external auditory meatus, and 3 in. above Reid's base line. A crown of trephine was removed, and after a ridge of bone had been sawn off by a Hey's saw Mr. Pick was able to prise up the depressed bone to its proper level. There was no injury to the dura mater. No ligature was required. I drainage-tube was inserted, the flaps united with silver sutures, and wet carbolised gauze dressings applied.

The patient passed a good night, and was cheerful and conscious next day. His temperature was irregular for a few days, and the wound was foul for four days. At the end of the first week the paralysis began to diminish, and from this time he slowly improved. The wound did well, and in five weeks the lad was sent to a convalescent hospital, on May 12th. At this time there was slight paresis of the arm and hand. He remained in the country five weeks, and on returning was found to have completely recovered the use of his hand and arm.

\section{GENERAL LYING-IN HOSPITAL}

CASE OF CERVICAL IEMPHYSEMA FOLLOWING PARTURITION REMARKS,

(Under the care of Dr. R. BoxALL.)

For the following notes we are indebted to Dr. W. G Holloway, house-physician.

Mrs. S - aged nineteen, a well-developed but somewhat delicate-looking primipara, was admitted towards the end of the first stage of labour on August 26th, 1886. Full dilatation of the cervix was reached at 10.20 A.M., and the head passed slowly through the pelvis in the first cranial position. It remained two hours on the perineum, and was eventually 